ENGLISH EDUCATION

English Journal for Teaching and Learning

Vol. 07 No. 01 June 2019 page 69 - 80

http://jurnal.iain-padangsidimpuan.ac.id/index.php/EEJ

\title{
Students' Anxiety on Their Public Speaking
}

\author{
Rini Kesuma Siregar* \\ Universitas Graha Nusantara (UGN) Padangsidimpuan \\ Email : ryenies@gmail.com
}

\begin{abstract}
The purpose of this research is to find out the anxiety of students when speaking in English in front of the public in SMK Teruna Padangsidimpuan. This study used qualitative research with descriptive methods. Data is taken from questionnaires and interviews with students. The results of this study indicated that students are at medium and serious level of anxiety because each student has different abilities. This shows that when a student speaks in front of the public they still feel anxious, especially because the anxiety factor is not confident, unable speak English and rarely appear in public.
\end{abstract}

Key Words : anxiety; public speaking; confident; feeling anxious; abilities.

Abstrak Tujuan dari peneltian ini adalah untuk mengetahui kecemasan siswa ketika berbicara dalam bahasa inggris di depan public pada siswa SMK Teruna Padangsidimpuan. Penelitian ini menggunakan penelitian kualitatif dengan metode deskriptif. Data diambil dari angket dan wawancara terhadap siswa. Hasil dari penelitian ini menunjukkan bahwa siswa berada pada tingkat kecemasan medium dan serius karena masing - masing siswa memiliki kemampuan berbeda.Hal ini menunjukkan bahwa ketika seorang siswa berbicara di depan public masih merasa cemas, apalagi factor kecemasan tersebut adalah karena tidak percaya diri, tidak mampu berbahasa inggris dan jarang tampil di depan umum.

Kata Kunci : anxiety; public speaking; confident; feeling anxious; abilities

E-ISSN : 2579-4043

P-ISSN: $2338-8781$

* Corresponding Author : ryenies@gmail.com 


\section{INTRODUCTION}

There are so many kinds of language in the world and one of the famous language that others world always used whatever they go is English. This language really has many influences for every people because English is not only a language for one person but also the ways to find new people, job and information. That's why English became as an important language especially in our country Indonesia.

Since long time ago English becomes a new subject of lesson in every school from kindergarten, junior high school, senior high school and university. Besides that, English is not only studied in school but every student who are not able to comprehend it in the school so they can take a course outside to make them study about English faster.

Speaking is the productive skill. It could not be separated from listening. When we speak we produce the text and it should be meaningful. In the nature of communication, we can find the speaker, the listener, the message and the feedback. Speaking could not be separated from pronunciation as it encourages learners to learn the English sounds.

Speaking has been regarded as merely implementation and variation, outside the domain of language and linguistic proper. Linguistic theory has mostly developed in abstraction from context of use and source of diversity. Therefore, Clark and Clark said that speaking is fundamentally an instrument act. Speakers talk in order to have some effect on their listener. It is the result of teaching learning process. Students' skill in conversation is core aspect in teaching speaking, it becomes vitally aspect in language teaching learning success if language function as a system for expression meaning and the successful in speaking is measured through someone ability to carry out a conversation in the language. We confess that there are many proponent factors that influence teaching speaking success and there are many obstacle factors why it is not running well.

Not everyone can speak confidences in public, because speak in daily life different when someone speak in front of many people. And one of the problem in public speaking is anxiety, it's really a big problem for student who never or rarely speak in public. 
Public speaking is an ability to speak in front of public. It can be give opinion in discussion situation, speech, introduce ourselves, present papers, anytime and anywhere. Public speaking skills are not absolute belongs to great figures such as presidents, ministers, or high officials who often speech in a big event is very much awaited. Nor is absolute belonging to a celebrity or a leading $\operatorname{arti}^{1}$ st who often appears on the screen. Public speaking skills belong to all citizens. ${ }^{1}$

Anxiety is a feeling disorder which is characterized by feelings of fear or worries deep and sustainable. Something that make a person often feel anxious, like when speaking in front of public, will take the test, face interview and so on. Basically, anxiety is a natural thing that every human being has ever experienced. Anxiety is already considered a part of everyday life. Anxiety is a state of the soul that is full of fear and fear of what might happen, both with regard to the limited problem and the strange things. The general description of anxiety is "feelings of distress and uneasiness, and chaotic thinking with lots of regret". This is very influential on the body, until the body feels shivering; causing a lot of sweat, fast heart pounding, stomach feel nausea, the body feels weak, decreased productivity ability, until many humans who escaped into the imagination as a form of temporary therapy. "Anxiety is a general feeling, where one feels fear or loss of self-confidence that is not clear origin or form" ${ }^{2} 2$

"Anxiety is anxiety, fear that is not clear why. Anxiety is also a major force in moving behavior, either distorted or disturbed behavior. Both are statements, appearances, the embodiment of defense against the anxiety". ${ }^{3}$ anxiety is the response of a real or imaginary threat. Individuals experience anxiety due to uncertainty in the future". 4

1Sirait, Charles Bonar. 2008. The Power of Public Speaking: Kiat Sukses Berbicara di Depan Publik. Jakarta: PT Gramedia. Pg.18

2Sutardjo Wiramihardja. (2005). Pengantar Psikologi Abnormal.Bandung: Refika Aditama.Pg.66

${ }^{3}$ Gunarsa, Singgih D. 2008. Psikologi Anak: Psikologi Perkembangan Anak dan Remaja. Jakarta: PT BPK Gunung Mulia.Pg.27

${ }^{4}$ Lubis, Namora Lumongga. 2009. Depresi : Tinjauan Psikologis. Jakarta : Kencana Prenada Media Group. Pg.14 
The conclusion can be drawn from some of the above opinions that anxiety is fear or worry in certain situations that are very threatening that can cause anxiety due to uncertainty in the future and the fear that something bad will happen.

\section{METHOD}

In order to get the accurate data, the method of this research is qualitative research. In qualitative research, research is done on the object of natural meaning, the object that developed as it is, not manipulated by the writers and the presence of researchers does not affect the dynamics of the object.

\section{The Technique of Collecting Data}

Collecting data is a very important step in the research, therefore a researcher must be skilled in collecting data to obtain valid data. Data collection is a systematic and standard procedure for obtaining the necessary data. It is impossible to collect data from respondents without any tools.

\section{a. The Observation}

Observation is the way to collect the data where the writer pay attention to the informants activity directly. Before made the research the writer did some observation to SMK Teruna Padangsidimpuan because its important to get permissions to the headmaster then observed the interested of the students in English and the last the writer prepared some important things to did the research.

\section{b. Interview}

The data in this research is qualitative form, so the instruments used in this study are interview, direct observation and documentation of teaching and learning process. Instrument is the tool that the researcher uses in collecting the data from the respondent of the research. The interview is the instrument to collect data by using written question. The writer started the interview from headmaster, English teacher and some of the students in SMK Teruna Padangsidimpuan. 


\section{Technique of Data Analysis}

The data that were collected from the research field then gathered to put into analysis. Qualitative data often consists of interview notes or transcripts, notes from the observation in the field, or written documents and recorder. Then, the data would be written in notes, transcripts or other data.

There were several ways in analyzing the data, they were describing, classifying and interpreting. In describing, the researcher described all the data that the researcher got in the field based on the problems from observation checklist and interview guide. Second is classifying, the data. Classifying data was needed in order to put data into each type and to analyze them partly based on each indicator. And the last is interpreting. Here, the researcher determined the data. Interpreting was done before writing the research report in order to make sense of the data by synthesizing and summarizing the data, and the result of analysis was not reported in numerical description.

\section{RESULT AND DISCUSSION}

The data of students' anxiety problem especially on their public speaking performance was collected by the researcher through observation, interview, and questionnaire. In observation process, the researcher sat on the teacher's chair at the eleventh grade accounting students of SMK Swasta Teruna Padangsidimpuan class. From the interview, there are ten items should answered by the informants.

\section{An Analysis of Students' Public Speaking With Medium Anxiety}

Students $\mathrm{A}$ is a eleventh grade accounting students of SMK Swasta Teruna Padangsidimpuan who has born on March 26 2002 in Tangga Batu. She lives in Sadabuan, Padangsidimpuan.

From the interview data which is taken by the researcher, her favorite subject is reading. She want to improve her English knowledge and to more understand about English language. So she likes reading to improve it. Besides reading, she also likes speaking. Because according to her, if we able to speaking well, the other people will understand what we said. The problem that she usually faced when she is trying to speak is nobody want to give respond to her in English language. 
When she is going to speak in front of the public, she make preparation such as learn some of matery and try to prepare vocabulary more. Sometimes she is easy to panic particularly when there is someone who laugh when she tries to speak and it makes her forget about the matery that she will deliver.

She includes someone that difficulty concentrating when speak in front of public, but she is no phobia person. To eliminate feelings of anxiety when speak in front of public she try to more exercise in front of mirror and she speaks alone in her room.

From all the data which is taken from Student A, the researcher concludes that actually, he is still feel anxiety when speak in front of public. Eventhough she has low anxiety. The researcher can see from the result of structure observation spontaneously in explanation her speech she still anxiety it proved she has seen speak as not focus on her audience, there is pause between word to word but not long pause. But, she has good pronunciation, fluently in speaking english. So, as the way to eliminate feelings of anxiety, she still has efforts try to more exercise in front of mirror and speaks alone in her room.

Student B was born on August 17th, 2002 in Batubara. She lives in Sialogo. Student B has same opinion with student A. She also feels anxiety on their public speaking performance. She likes reading because with reading she can add her knowledge. She likes speaking also, because she really want to able to speak with English language fluently. She has some problem with Student A when she try to speak English, that is there is nobody want to give the feedback to her with English language also. And some of her friends said that she want to show up her speaking ability, and it makes her down.

She always makes the preparation before speaking in front of public. She get difficulty in concentrating when she look at her friends face, but she is not a phobia person when speak in front of public. To eliminate her anxiety when speaking in front of public, she just need to hold something small like a pen or pencil. It can reduce her anxiety according to her.

Based on interviewing, the researcher concludes that Student B still has anxiety when speaking in front of public. Eventhough she can reduce her anxiety by holding something. From the observation, the researcher can see that sometimes she have paused when deliver her speech, and sometimes she is not 
focus to the audience. It means that, eventhough she has effort to reduce her anxiety, she still feel it.

Student C was born on April 18th, 2001 in Batang Baruhar Jae. She lives in Gg. Man, Padangsidimpuan. Her favorite subjec is English. She likes speaking very much because she wants to be an English teacher. The problem she faced when speak by using English language is afraid to make mistakes. So, when she wants to start speaking she always prepare it by thinking about the grammar.

Besides that she is difficult to concentrating when speaking and she is a phobia person when speaking in front of public. The effort to eliminate that, she try to memorize everything that she want to say.

Ellis also still have anxiety when speaking in front of public, and it looked when the researcher did the observation. When she delivered the speech, sometimes there is pause between word to word but not long pause. But, she has good pronunciation, fluently in speaking English.

Student D was born on August 10 1 th 2001 in Huta Padang. She lives in Palopat Maria, Padangsidimpuan. She likes Math and English. From the four skills in English, she likes speaking because she feel well to express her mind. When speak in front of public, she feels nervous palpitations, moving the foot. Before speaking, sometimes she makes the preparation. She is easy to panic when speak in front of people, and sometimes what her know is blank when she speak. But she is not phobia person. To eliminate the feelings of anxiety her effort is she often speak alone and make some exercise to speak when she take a bath.

Based on interviewing, the researcher concludes that student D feels low anxiety. It proved from result of structure observation in explanation her speech spontaneously she focus on audience, fluently in speaking English, more relax in delivering speech. Eventhough, sometimes she is forget what will say and there is pause word to word when speak in front of public. So that, She have some efforts to eliminate feelings of anxiety when speak in front of public such as she often speak alone, exercise to speak when her take a bath.

Based on the explanation above, four informants that has result of questionnaire data is low anxiety, when they asked speak in front of public spontaneously of observation in her speech in fact, they are more fluently speaking in English, not mix Indonesia language and more relax in delivering 
speech in front of audience. But they still have some sympton anxiety when delivering speech, they seen not focus on the audience and there is pause word to word but not long pause. It still must be avoived by the students.

\section{An Analysis of Students' Public Speaking With Serious Anxiety}

Student E was born on December 24th 2001 in Kampung Setia. She lives in Kampung Setia. Her favorite subject is Math. She likes speaking. But the problem is when she speak in front of public, she feels nervous, panic and often pressing the thub and put her hands behind her waist. She always makes the preparation before speak in front of public especially by using English language. She is easy to panic, because she can not confidence speak in front of public. She often feels difficult concentrating but she is not phobia person. To eliminate feelings of anxiety, she have some efforts such as always does the exercise in front of mirror and speak alone.

Based on interviewing, the researcher concludes that $\mathrm{E}$ is high anxiety and not confident when speak in front public. It proved from the result of structure observation in explanation her speech that she still high anxiety, seen from anxiety sympton with put her hand behind, often move her hand and seen blank what will say. There is long pause from word to word and less vocabulary so that she mix Indonesia and English.

Student F was born on May 8th, 2000 in Siijuk. She lives in Sialogo. Her favorite subject is English, and she likes speaking because with speaking she can share everything on her mind. But when speak in front of public, she is too panic and it makes her blank. She is forget everything she want to say.

Before speaking, she always make the preparation like memorizing the sentence. Because of her panic, she is difficult to concentrating when speak to public. She is a phobia person. To eliminate that feeling, she always does the practice in speaking.

Based on the interviewing, Student F has high anxiety. It looked when the observation. She often move her body especially her hands and legs. There are more paused when she speak and sometimes she forgot about the speech that she want to deliver. Eventhough, she has effort to eliminate that feeling by doing practice in speaking. 
Student G was born on November 13rd, 2002 in Marancar Julu. She lives in Marancar Julu. She likes English subject and speaking. The problem she often faced when speaking is she often feels shy. Before she speak, she usually makes preparation such as memorize the words and find out the English of word that she doesn't know. She doesn't have difficulty in concentrating, but she is a phobia person. If there is someone laugh when she speaks, she will stop and follow her friends to laugh. To eliminate the problem, she always makes more preparation to make sure that she can do it.

Based on the interviewing, Ropia has high anxiety. The fact showed when the researcher did the observation. She stop speaking in many times when looking her friends, and move her body. Besides that she looked palefaced in her speech performance.

Student H was born on February 22nd, 2001 in Huta Padang. She lives in Huta Padang. Her favorite subject is Bahasa Indonesia. She doesn't like speaking because according to her, speaking by using English language is a difficult thing. The problem is she lack in pronounce the word. Because of her opinion that speaking is difficult, she never try to able to speaking well. She always makes mistakes when saying something eventhough she has prepared it, and it makes her always feels anxiety when speaking in front of public. She haven't difficulty concentrating when speak to public and she is not a phobia person. To eliminate that feeling, she usually moves her body and looks to the ceiling of the room.

Based on the data, student $\mathrm{H}$ has high anxiety. It appropriate with the observation result that shows her anxiety. When performing her speech, she is difficult to say each words, and always makes mistakes. Besides that, when speaking, there are some long pause from word to word. Although she move her body and looked to the ceiling, her anxiety is still looked form her face.

From explanation based on four informants that has high anxiety, they are more difficult to control their anxiety when speak in front of public. Such as they are often move her body, laugh in front of audience and they are forget what will they say . It means that they need to develop their speaking skill in public and eliminate their feeelings of anxiety.

From analysis of structure observation that has been conducted in SMK Swasta Teruna Padangsidimpuan, the researcher concludes that the problem on 
students' anxiety on their public speaking performance are: 1) The student most high anxiety is 83 and the student most low anxiety is 52. 2) Students that has low and high anxiety when they are spontaneously asked speak in front of public, they still have anxiety eventhough different intensity of anxiety. 3) Students low anxiety, eventhough they seen still anxiety and have some sympton anxiety but the fact they are more fluently, more relax speak in front of the audience and not mix indonesia language. 4) Students high anxiety they seen often forget what they will say, not focus on their audience, mix indonesia language in delivering speech, showing a little of laugh in front of audience, move her body and feel panics.

From the data collected the researcher need to align some fact that there are some problems in public speaking performance especially in students' anxiety. The eight students involve four low anxieties and four high anxieties have the different result of analysis when delivering speech. The low anxiety when speak in front of the public still feel anxiety even though low anxiety, but they are more seen fluently speaking English, relax in delivering speech. Meanwhile, the students high anxiety seen not focus on the audience, often move her body, mix Indonesia language in delivering speech, laugh in front of audience and they are forget what will they say. It is very disturb them when speak in public. So that, it must be avoided. As the student high level, the students should be eliminate their anxiety when speak in front of public. It can be practice speak in front class such as they often give opinion in discussion, become moderator in present paper, follow English course to support their speaking skill. So that, they can speak fluently and correctly in front of audience.

The students must be able speaking in front of public. As the students, they should have ability to convey something or information to audience confidently with good fluency, clear pronunciation and well grammar. High anxiety caused feeling panics when speak in front of public and make students not focus on their audience, forget what will they say and often move their body when speak. So the student should be have efforts to eliminate their anxiety first before speak in front of public.

In observation and interview, students still mix Indonesian and English, they also difficult in express something, tell same word repeatedly and have long 
paused from word to word.. It means that the students still feel anxiety and it can make them very disturb when speaking in public. It is far from expectation.

In order to eliminate their anxiety on their public speaking performance the students should be often practice their selves such as practice speak in front of mirror, practice speak with their classmate, they have to get used to speaking in front of crowds. If the student can apply that, their ability in public speaking performance which is hoped will be reached well.

\section{CONCLUSIONS}

Anxiety feeling of students at the eleventh grade accounting students of SMK Swasta Teruna Padangsidimpuan especially for the eight informants, involved that four informants serious anxiety and four informant medium anxiety when they asked to delivering speech spontaneously still anxiety even though they have different intensity. It made them not fluently delivering speech. It still far from expectation. They felt some anxiety sympton. It proved, they felt palpitation suddenly hot cold on their body, pressing the thumb and put her hands behind her waist. So that, make them forget what they will say, showing a little of laugh in front of audience, not focus on their audience, move her body and panics. Their anxiety when spoke in front of public, it is very disturb them. Students should be eliminate their anxiety when speak in front of public.

Students' public speaking performance with medium anxiety, they more relax, fluently when spoke in front of the audience, and they have good pronounciation in high school students level. Meanwhile students with high anxiety seen not relax when performing their speech. There are something disturb them such as forget what they will say, move the body in many times, feel panics and so on.

\section{REFERENCES}

Chaney, A. L and T. L. Burke. Teaching Oral Communication in Grades K-8. Boston: Allyn \& Bacon, 1998.

C. Richards, Jack and Willy A. Renandya, Methodology in Language Teaching, (United Kingdom: Cambridge University Press, 2002) 
E. Mills, Geoffrey, Action Research a guide for The Teacher Researcher, (New Jersey: Prentice Hall, 2000).

Felder, R. M. How to Improve Teaching Quality. (Quality Management Journal, 6 (2), 9-21, p. 1. 1991.

Gay, L.R and Peter Airasian, Educational Research; Competences for Analysis and Application, (New Jersey: Prentice - Hall, Inc, 2000).

Gunarsa, Singgih D. 2008. Psikologi Anak: Psikologi Perkembangan Anak dan Remaja. Jakarta: PT BPK Gunung Mulia.

Harmer, J. How to Teach English: An Introduction to the Practice of English Language Teaching. Malaysia: Longman, 2004.

Hornby, A. S. Oxford Advanced Learner's Dictionary. New York: Oxford University Press, 2003.

Hughes, A. Testing for Language Teachers. USA: Cambridge University Press, 1990.

J. Weir, C. Communicative Language Testing. Prentice Hall: University of Reading, UK, 1990.

Lubis, Namora Lumongga. 2009. Depresi : Tinjauan Psikologis. Jakarta : Kencana Prenada Media Group.

Richard-Amato, Patricia A., Making It Happen: From Interactive To Participatory Language Teaching, New York: Pearson Education Inc: New York, 2003.

Richards, Jack C., and Theodore Rodgers. Approaches and Methods in Language Teaching. Second Edition. Cambridge University Press: Cambridge, 2001

Sirait, Charles Bonar. 2008. The Power of Public Speaking: Kiat Sukses Berbicara di Depan Publik. Jakarta: PT Gramedia.

Sutardjo Wiramihardja. (2005). Pengantar Psikologi Abnormal. Bandung: Refika Aditama. 